\title{
Recruitment in a scent trail laying stingless bee (Scaptotrigona aff. depilis): Changes with reduction but not with increase of the energy gain*
}

\author{
Veronika M. SCHMIDT ${ }^{\mathrm{a}}$, Ronaldo ZUCCHI ${ }^{\mathrm{b}}$, Friedrich G. BARTH ${ }^{\mathrm{a}}$ \\ ${ }^{a}$ Department of Neurobiology and Behavioral Sciences, Faculty of Life Sciences, University of Vienna, \\ Althanstrasse 14, 1090 Vienna, Austria \\ b University of São Paulo, FFCLRP, Department of Biology, Avenida Bandeirantes 3900, 14040-901 Ribeirão \\ Preto, SP, Brazil
}

Received 31 October 2005 - revised 7 December 2005 - accepted 20 December 2005

\begin{abstract}
How does the sugar concentration of the food source affect the recruitment of Scaptotrigona aff. depilis? We offered sugar water of either constant, increasing, or decreasing concentrations. Simultaneously, we recorded the number of recruits and the recruiters' running speed, jostling contacts, and vibrations inside the nest. Neither the number of recruits nor the behavioral parameters depended on the actual sugar concentration but rather on the changes experienced over time. Concentration increases neither led to increased numbers of recruits nor to increased recruitment activity. Concentration decreases resulted in significantly decreased numbers of recruits. However, most parameters of intranidal activity changed significantly only when the concentration was reduced from $40 \%$ to $20 \% \mathrm{w} / \mathrm{w}$ and recruitment to the food source nearly ceased. These findings support the idea of a feedback mechanism reducing the colony's effort to exploit food sources of decreasing profitability.
\end{abstract}

stingless bee / recruitment / foraging / food profitability / communication / Apidae / Meliponini

\section{INTRODUCTION}

One of the key questions in regard to the recruitment behavior of social insects is which parameters regulate the recruitment process and thus the number of recruits actually appearing at a food source. Among the many factors (season, time of the day, temperature, humidity, location and quality of the food source, nutritional state of the colony, etc.) known to affect recruitment in social bees food profitability appears to have a particularly strong impact, as one would expect (Lindauer, 1948; Boch, 1956; von Frisch, 1965; Roubik, 1989; Seeley, 1995). Honeybees gauge the energy gains at the food source by means of the sugar

Corresponding author: V.M. Schmidt, veronika.schmidt@univie.ac.at

* Manuscript editor: Marla Spivak uptake rate $(\mathrm{mg} / \mathrm{s})$ and the amount of sugar (mg) carried by the forager (Farina and Núñez, 1991). They increase both the number of recruits and their intranidal recruitment activity with increasing energy gains and reduce both with decreasing food profitability (e.g. von Frisch, 1965; Seeley, 1995). Likewise a few non-scent trail laying stingless bees were shown to recruit more nestmates to highly concentrated sugar water than to a less concentrated one (Johnson, 1987; Bartareau, 1996; Biesmeijer and Ermers, 1999) and to increase intranidal recruitment activity with increasing food profitability and vice versa (Aguilar and Briceño, 2002; Nieh et al., 2003; Hrncir et al., 2004b).

In contrast, recent work demonstrated that in a stingless bee, which lays a scent trail between the food source and the nest, the recruitment to food sources of different profitabilities was 
more similar to that of scent trail laying ants than to that of honeybees or non-scent trail laying stingless bees (Schmidt et al., 2006). In both these species of stingless bees and ants the number of recruits not only depended on food profitability, but also on the sequence of discovery of the food sources (ants: Beckers et al., 1990; Nicolis and Deneubourg, 1999; Sumpter and Pratt, 2003). In scent trail laying ants food profitability affected both the number of recruits and the recruitment activity of the individual forager (Breed et al., 1987; Pasteels et al., 1987; Beckers et al., 1990, 1993; Fewell et al., 1992; Mercier and Lenoir, 1999; Cassill, 2003; Sumpter and Beekman, 2003). Although in scent trail laying stingless bees the number of recruits was shown to be affected by food profitability (Schmidt et al., 2006) there are no studies yet clarifying the dependence of the recruitment activity on food profitability.

In the present study we investigated whether changes of the sucrose concentration entail changes in the number of recruits and in the intranidal recruitment behavior of Scaptotrigona aff. depilis, a stingless bee which lays a scent trail to guide recruits to a food source (Lindauer and Kerr, 1958). Particularly, we asked the following questions: (i) How does the energy intake of Scaptotrigona aff. depilis change when the sugar concentration is varied within its biologically relevant range? (ii) How is the number of recruited nestmates related to the forager's energy intake? (iii) Does intranidal recruitment behavior depend on the changes in sucrose concentration previously experienced? (iv) Does the sugar concentration influence the forager's thorax vibrations inside the nest?

\section{MATERIALS AND METHODS}

\subsection{Study site and bees}

All experiments were performed on the Ribeirão Preto campus of the University of São Paulo between January and April in 2003 and in 2004. The study colony of Scaptotrigona aff. depilis Moure 1942 was kept inside the laboratory in a wooden box with a plastic tube inserted through the wall of the building and serving the bees as entrance and exit. To be able to record the behavior of the bees we placed a wooden box $\left(5 \times 10 \times 2 \mathrm{~cm}^{3}\right)$ between the nest and the entrance and exit tube which the bees quickly accepted as part of their nest (Hrncir et al., 2000). The foragers spent most of their intranidal time inside the recording box and performed their normal recruitment behavior in it.

The box was either covered by glass for video recordings or by a transparent foil slide for laservibrometry. The use of one colony only is justified by the fact that our aim was to uncover basic mechanisms which we assume not to principally differ between colonies in agreement with all previously made experience.

\subsection{Recording the food intake}

In order to determine the food and energy intake at different sugar water concentrations we examined ten individual bees per concentration (ambient temperature $27.1-32 \cdot 1^{\circ} \mathrm{C}$ ). A known volume of sugar water with a concentration of either $20 \%, 40 \%$, or $60 \% \mathrm{w} / \mathrm{w}$ was placed onto a Plexiglas ${ }^{\circledR}$ disc using a $50 \mu \mathrm{L}$ micro-capillary (Sigma, microcaps) immediately upon a bee's arrival at the feeding site $50 \mathrm{~m}$ away from the nest. The sugar water was unscented and prepared from unrefined cane sugar $(99.8 \%$ sucrose, $0.1 \%$ glucose and fructose, $0.1 \%$ mineral salts). Its concentration was measured with a field refractometer (Krüss Optronic HR 25/800). The time spent by the bee taking up the sugar water was measured with a stop watch to the nearest $0.1 \mathrm{~s}$. The remaining sugar water was removed with a $50 \mu \mathrm{L}$ micro-capillary immediately after the bee had left the feeder in order to reduce evaporative losses. The imbibed crop load $(\mu \mathrm{L})$ was determined as difference between the amount of sugar water before and after the bee's food intake. The solution intake rate $(\mu \mathrm{L} / \mathrm{s})$, the total amount of sugar per crop load (mg), and the sugar intake rate $(\mathrm{mg} / \mathrm{s})$ were calculated from the feeding time and the amount of sugar water imbibed.

A $20 \% \mathrm{w} / \mathrm{w}$ sugar water concentration corresponds to a molarity of $0.63 \mathrm{M}$ and a viscosity of about 1.5 centistokes $(\mathrm{cSt})$ at $30^{\circ} \mathrm{C}$ solution temperature. For $40 \% \mathrm{w} / \mathrm{w}$ and $60 \% \mathrm{w} / \mathrm{w}$ the values are $1.38 \mathrm{M} / 3.2 \mathrm{cSt}$ and $2.26 \mathrm{M} / 24.3 \mathrm{cSt}$, respectively (Weast et al., 1989; Chenlo et al., 2002). According to observations on natural food sources Scaptotrigona spp. collects nectar with sugar concentrations between $10 \%$ and $69 \%$ w/w (Roubik et al., 1995). The concentrations used in our experiments were within this biologically relevant range.

\subsection{Training procedure and experiments}

Between $11.00 \mathrm{~h}$ and $12.00 \mathrm{~h}$ we trained from three to six foragers to a feeding site $50 \mathrm{~m}$ away from 
the nest, presenting $13 \% \mathrm{w} / \mathrm{w}(=0.4 \mathrm{M})$ sugar solution in feeders as described by Jarau et al. (2000, 2003). The direction from the nest to the feeder was changed daily in order to avoid the appearance of reactivated foragers and inspector bees at a feeding site already known to them (Biesmeijer and de Vries, 2001). Three of the trained foragers were individually color marked with Acrilex ${ }^{\circledR}$ plastic paint. All other bees were captured at the feeding site and caged until the end of the experiment. The three foragers visited the training feeder regularly but did not recruit nestmates to it. The feeder was then put away into an airtight plastic container and, subsequently, the new sugar solution with its respective concentration was offered to the bees in a clean but otherwise identical feeder. The experiment started when one of the three trained foragers took up the new sugar solution. During the experiment the three bees were allowed to feed ad libitum. All experiments started between $12.00 \mathrm{~h}$ and $13.00 \mathrm{~h}$ and lasted for three hours. Every newly arriving bee (defined as recruit) was captured and its time of arrival recorded. The danger of misinterpreting scouts finding food sources without using recruitment communication (Biesmeijer and de Vries, 2001) as recruits was negligible. According to previous studies hardly any bee arrives at an artificial feeder when no nestmate is feeding on it (Schmidt et al., 2003). Other nests of Scaptotrigona aff. depilis occurring in the area of the experiments were closed in the morning of experimental days. Thus all newcomers were from the colony under study only. Additionally, we marked every captured bee with a colored dot before its release. Bees marked with the color of our experiments were never found at the nest entrance of any other colony.

The influence of food profitability on the number of recruits was tested by three series of experiments: (a) control: constant sugar water concentration (40\%) over the entire time span of three hours; (b) increasing concentration: hourly changes of the sugar water concentration from $20 \%$ to $40 \%$ and to $60 \% \mathrm{w} / \mathrm{w}$; and (c) decreasing concentration: hourly changes from $60 \%$ to $40 \%$ and to $20 \% \mathrm{w} / \mathrm{w}$. The sugar concentrations were verified with a field refractometer (Krüss Optronic HR 25/800) immediately before and after each experiment. We used a fresh alcohol-cleaned feeder whenever the sugar water concentration was changed. The feeding dish was changed hourly during the control series as well. Each test series $(a, b, c)$ consisted of six individual experiments conducted in random order on different days.

Throughout an experiment the behavior of the recruiting bees was recorded in one of two ways: (1) In three out of six experiments each with increasing and decreasing sugar concentrations we videotaped the behavior of the recruiters in a glass-covered recording box inside the building. (2) In three out of six experiments each with increasing and decreasing concentrations we recorded the thoracic vibrations of the recruiting bees inside the recording box with a portable laser-vibrometer (Polytec, PDV 100). Any distortion of the signal by the passage of the laser-beam through the foil covering the box can be excluded for frequencies lower than $4 \mathrm{kHz}$ (Hrncir and Schmidt, unpublished data). The laser-vibrometer was mounted on a four wheeled cart. A mirror directed the laser beam onto the bee (Hrncir et al., 2004a). The vibrometer output was stored on a PC (sampling rate $22.05 \mathrm{kHz}$; 32-bit sound card; Soundforge 4.0, Sonic Foundry Inc.). In the recording box the foragers unloaded food and showed recruitment behavior as they usually do in the front part of their nest close to its entrance (Hrncir et al., 2000, 2004b).

\subsection{Data analysis}

(1) In order to quantify the recruitment behavior inside the nest $(\mathrm{n}=9$ bees per test series) the digitized video material was analyzed using the software Videopoint 2.5 (LENOX Softworks). We counted the number of jostling contacts of each recruiter with her nestmates during the time spent running inside the recording box. Jostling contacts (Hrncir et al., 2000) were classified as contacts when the recruiter bumped into a nestmate, thus displacing it or changing its running direction (Fig. 3a). From the number of jostling contacts per observation time we calculated jostlings/second. The average running speed $(\mathrm{cm} / \mathrm{s})$ of each recruiter over the time of six video frames upon entering the recording box was taken as another measure of intranidal activity. Running events were used for analysis only if the bees did not stop for trophallaxis during or shortly after the time of the measurement. We did not average the bees' running speed over a longer time span because the time spent with trophallaxis inside the recording box would have biased the result.

(2) The vibrations of the recruiting bees ( $\mathrm{n}=9$ bees per test series) were analyzed using the software SpectraPro 3.32 (Sound Technology Inc.). The duration (s) of the pulses, pauses, and of the pulse sequence (= pulse + subsequent pause), the duty cycle (= pulse / pulse sequence), the main frequency $(\mathrm{Hz})$ contained in every pulse, and the velocity amplitude $(\mathrm{mm} / \mathrm{s})$ of every pulse were measured. The procedure followed Hrncir et al. (2004a, b).

\subsection{Statistical analysis}

Data were analyzed using SigmaStat 3.1 (SPSS Inc.) software. In cases of a normal distribution (confirmed by the Kolmogorov-Smirnov-test; $P>0.05$ ) the data were presented as mean percentages $( \pm \mathrm{SD})$ and parametrical tests applied (one way ANOVA). 

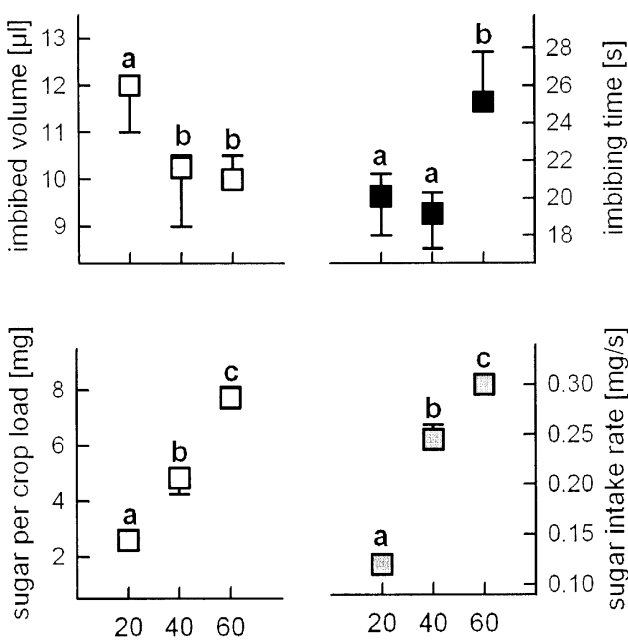

sugar water concentration [\% w/w]

Figure 1. Food intake by $S$. aff. depilis. The amount of sugar water imbibed was significantly highest when $20 \%$ w/w sugar water was offered (empty squares) and the imbibing time was significantly longest when bees fed on $60 \%$ sugar water (black squares). Both the total amount of sugar per crop load (gray squares) and the sugar intake rate (dark gray squares) significantly increased with sugar concentration. Different letters mark significant differences between the groups.

In cases of the non-normal distribution (KolmogorovSmirnov-test; $P<0.05)$ median percentages were given and non-parametric tests applied (one way ANOVA on ranks) (Sokal and Rohlf, 1995). $\chi^{2}$-tests served to examine whether the percentage of recruits per hour differed significantly from a random distribution during every individual experiment $(P<$ 0.05). In all graphs the values given represent median values for different periods of the experiment. Lower and upper error bars represent the $1 \mathrm{st}$ and the 3rd quartile of the data. Different letters next to the symbols mark significant differences $(P<$ $0.05)$ between the values. The significance level in all of our tests was defined as $P<0.05$.

\section{RESULTS}

\subsection{Sugar concentration and food intake}

The concentration of the sugar solution affected all the measured and calculated parameters of the bees' food intake (Fig. 1). The volume of the sugar water imbibed by the bees was significantly larger $(11.65 \pm 1 \mu \mathrm{L})$ when its concentration was $20 \% \mathrm{w} / \mathrm{w}$ than when it was $40 \%(10.0 \pm 1 \mu \mathrm{L})$ or $60 \%(10.2 \pm 1.1 \mu \mathrm{L})$ (ANOVA: $\mathrm{F}_{2,27}=7.15$; Tukey's comparison). Due to the higher viscosity the time a bee needed for the food intake was significantly longer $(25.8 \pm 1.95 \mathrm{~s})$ for the $60 \%$ sugar water than for the lower concentrations $(19.1 \pm 1.7 \mathrm{~s}$ at $40 \%, 19.6 \pm 2.8 \mathrm{~s}$ at $20 \%$ ) (ANOVA: $\mathrm{F}_{2,27}=$ 28.9; Tukey's comparison). As a consequence, the solution intake rate significantly decreased from the $40 \%$ to the $60 \%$ sugar solution from a median of $0.52 \mu \mathrm{L} / \mathrm{s}$ to $0.39 \mu \mathrm{L} / \mathrm{s}$ (ANOVA on ranks: $\mathrm{H}=22.04$; Dunn's comparison). In contrast sugar (and energy) uptake increased with sugar concentration. The median amount of sugar per crop load increased significantly from $2.59 \mathrm{mg}$ at $20 \%$ to $4.83 \mathrm{mg}$ at $40 \%$ and to $7.72 \mathrm{mg}$ at $60 \%$ (ANOVA on ranks: $\mathrm{H}=26.03$; Dunn's comparison). Accordingly, the median sugar intake rate also increased significantly with the sucrose concentration from $0.12 \mathrm{mg} / \mathrm{s}$ to $0.25 \mathrm{mg} / \mathrm{s}$ and to $0.3 \mathrm{mg} / \mathrm{s}$ (ANOVA on ranks: $\mathrm{H}=25.8$; Dunn's comparison).

\subsection{Sugar concentration and number of recruited bees}

The total number of recruits after three hours (newcomers appearing at the feeder) differed from day to day $(\min =18, \max =126)$. It was taken as $\mathrm{n}=100 \%$ in each experiment to allow comparison. The percentage of recruits per hour was chosen as a measure of recruitment effectiveness (Jarau et al., 2003).

Although the sugar water concentration did not change during control experiments, the number of recruits often did. In five out of six experiments the percentages of recruits per hour differed significantly from a random distribution $\left(\chi^{2}\right.$-tests). However, the mean percentages of recruits in three hours (Fig. 2) did not differ significantly at a sugar water concentration of $40 \%$ (ANOVA: $\mathrm{F}_{2,15}=0.07$; number of bees $n=67 \pm 33 /$ trial).

Interestingly, the same was true for the number of newcomers when the sugar concentration increased. Within three out of six experiments the percentages of recruits varied significantly ( $\chi^{2}$-tests). Only during one of them a steady increase was recognizable. The mean percentages of recruits (Fig. 2) did not 


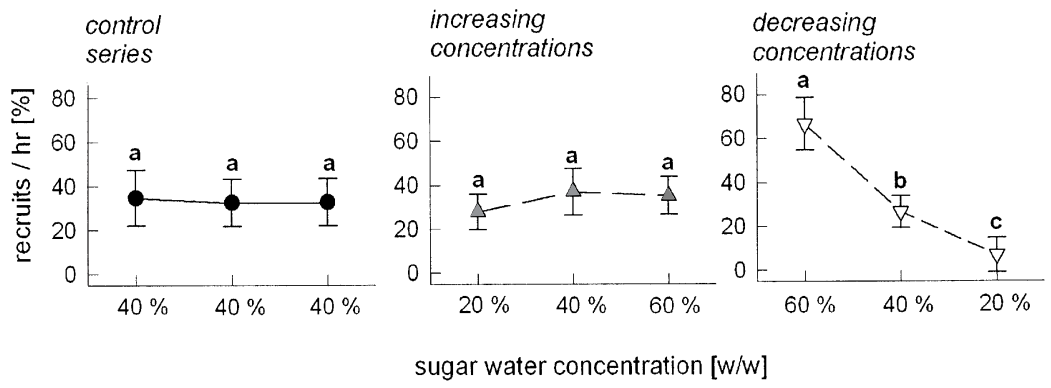

Fig. 2. Recruitment of $S$. aff. depilis to food sources of either constant (control) or varying profitability (increasing and decreasing concentrations). $100 \%=$ total number of recruits per experiment. Different letters mark significant differences. Control series: The mean percentage of recruits remained the same when $40 \%$ sugar water was offered for three hours $(P=0.93)$. When increasing the sugar concentration the percentage of recruits did not change significantly either $(P=0.21)$. However, after each reduction of the concentration the foragers brought significantly less recruits to the feeding site. Thus the percentage of recruits significantly decreased with reduction of food profitability $(P<0.001)$.

change significantly after any change to a higher sugar water concentration (ANOVA: $\mathrm{F}_{2,15}=1.75 ; \mathrm{n}=99 \pm 18$ /trial). $27.8 \pm 8 \%$ of the recruits arrived during the period when $20 \%$ sugar water was offered, $37.1 \pm 10.6 \%$ during the $40 \%$ concentration period, and $35.2 \pm 8.5 \%$ while the recruiters were feeding at $60 \%$ sugar water.

In contrast, the number of recruits decreased significantly in all six experiments when the sugar water concentration was reduced hourly $\left(\chi^{2}\right.$-tests). The mean percentage of recruits per hour (Fig. 2) declined significantly from $66.5 \pm$ $11.9 \%$ (at $60 \%$ ) to $26.6 \pm 7.3 \%$ (at $40 \%$ ) and to $6.9 \pm 7.8 \%$ (at 20\%) (ANOVA: $\mathrm{F}_{2.15}=64.65$; Tukey comparison; $\mathrm{n}=55.5 \pm 31$ /trial). During the period with $20 \%$ sugar water a strikingly low number of recruits arrived at the feeder $(0$ to 7 bees only). Thus, the reduction of the sugar concentration consistently led to significant changes of the recruitment process in Scaptotrigona aff. depilis.

\subsection{Jostling activity and running speed inside the nest}

When a forager returns from a valuable food source into the nest she runs around bumping into her nestmates (jostling contacts, Fig. 3a) and often stops for trophallaxis. In order to quantify the intensity of recruitment activity we measured the number of jostling contacts per unit time and the running speed of the forager. Both parameters did not change significantly with increasing sugar concentration (Fig. 3b, c) (jostling: ANOVA on ranks: $\mathrm{H}=4.4$; number of bees $\mathrm{n}=9$; running speed: ANOVA: $\mathrm{F}_{2,280}=$ $0.02 ; n=9$ ). The recruiters' jostling activity measured between 1.21 and 1.39 contacts/s (medians) at a mean running speed of 4.80 to $4.84 \mathrm{~cm} / \mathrm{s}$. Reductions of the sugar concentration from $60 \%$ to $40 \%$ neither significantly affected the jostling contacts per second nor the running speed (at 60\%: $1.69 \pm 0.6$ contacts/s and $5.13 \pm 1.1 \mathrm{~cm} / \mathrm{s}$; at $40 \%: 1.67 \pm 0.6 \mathrm{con}-$ tacts/s and $5.26 \pm 1.1 \mathrm{~cm} / \mathrm{s}$ ) (Fig. 3b, c). After having changed from $40 \%$ to $20 \%$ sugar water, however, both jostling contacts $(1.1 \pm 0.5$ contacts/s) and running speed $(4.27 \pm 1.2 \mathrm{~cm} / \mathrm{s})$ decreased significantly (jostling: ANOVA: $\mathrm{F}_{2,437}=39.5 ; \mathrm{n}=9$; Tukey's comparison; running speed: ANOVA: $\mathrm{F}_{2,438}=30.2 ; \mathrm{n}=9$; Tukey's comparison).

\subsection{Vibrations}

The vibrational signals produced by the foragers of $S$. aff. depilis were highly variable in regard to all of the analyzed parameters. Nevertheless, some interesting effects could be found when the sugar concentration was changed. Many signals consisted of a single continuous pulse with a duration of up to $18.8 \mathrm{~s}$. However, we never recorded such a signal when the bees were offered $20 \%$ sugar water during the series of decreasing sugar concentrations. During all the other periods with increasing and with decreasing concentrations the percentage of 
A
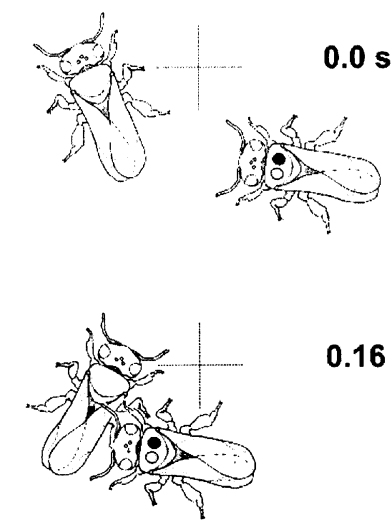

$0.16 \mathrm{~s}$
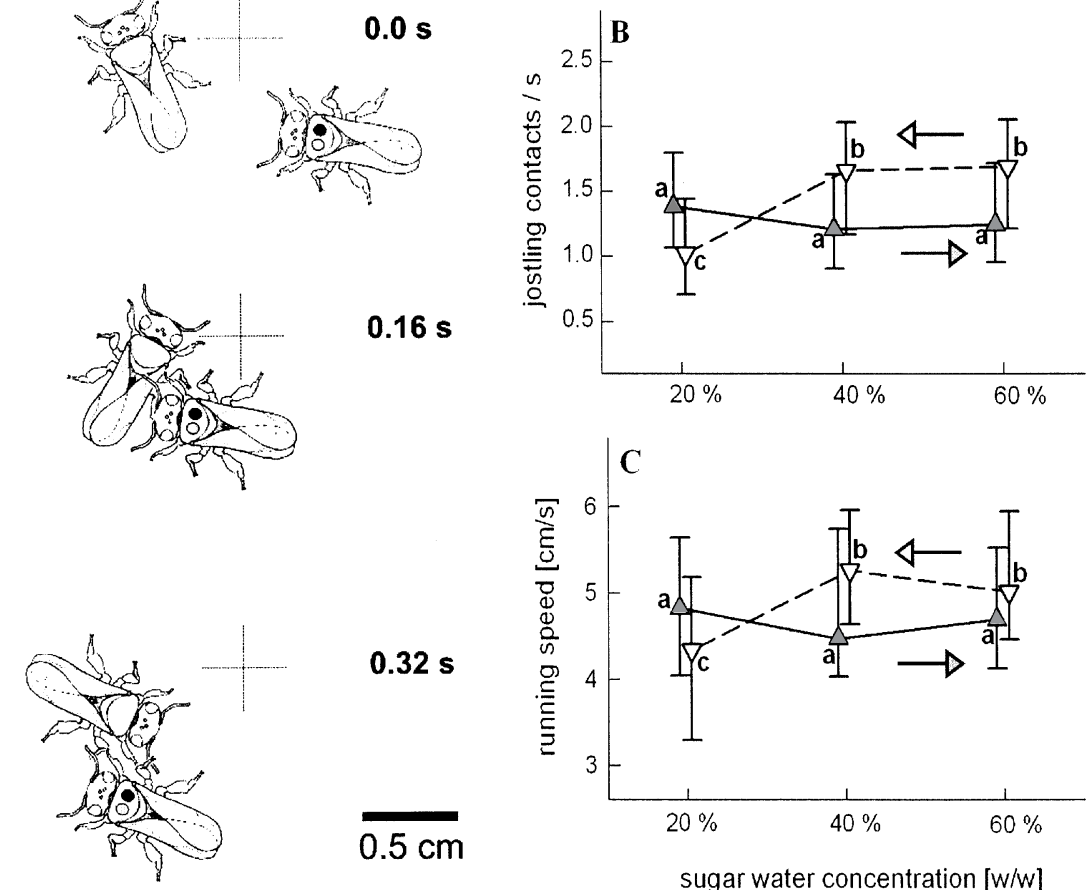

$0.32 \mathrm{~s}$

$0.5 \mathrm{~cm}$

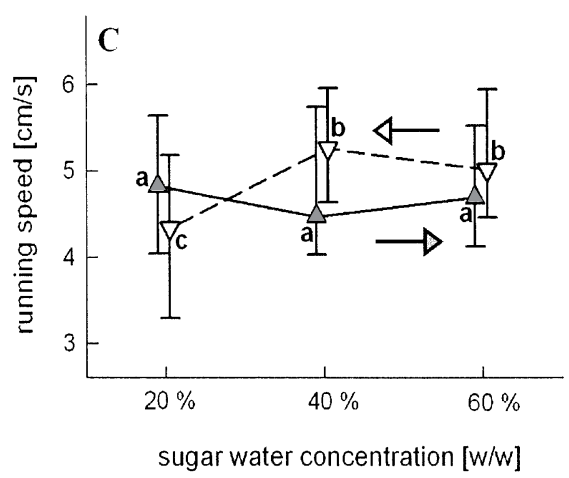

Fig. 3. (A) Typical jostling behavior of Scaptotrigona aff. depilis inside the nest. The recruiter is marked with two dots on its thorax. The nestmate is not marked. The bees' positions are shown relative to an imaginary spot (crossed dotted lines). (B) Intranidal jostling and (C) running speed of the foragers during the series of increasing $(\boldsymbol{\Delta})$ and decreasing sugar concentrations $(\nabla)$. Note that decreases of the sugar concentrations $(\nabla)$ are to be read from right to left, because the $60 \%$ concentration was offered during the first and the $20 \%$ concentration during the last hour of an experiment (see arrows). When experiencing increases of the sucrose concentration the recruiters neither significantly changed their jostling activity (B) nor their running speed (C). When reducing the concentration, only the change from $40 \%$ to $20 \%$ induced the bees to significantly jostle fewer nestmates per second (B) and to significantly reduce their running speed (C).

signals containing only a single pulse varied between $17 \%$ and $45 \%$. When $20 \%$ sugar water was offered first in a series of increasing concentrations $17 \%$ of the signals contained one single pulse as well. Thus, the signals consisting of one single pulse were only found in periods with many recruited nestmates but not when the foragers had almost stopped to bring recruits to the feeding site (Fig. 2).

Pulse duration, pause duration, pulse sequence, and duty cycle (Figs. 4, 5) did not change significantly with any increase of the sugar water concentration (ANOVA on ranks: $\mathrm{H}_{\text {pulse }}=6.4 ; \mathrm{H}_{\text {pulse sequence }}=0.72 ; \mathrm{H}_{\text {pause }}=$ 43.2; Dunn's comparison; $H_{\text {duty cycle }}=19.7$; Dunn's comparison). Nor did a reduction of the sugar concentration from $60 \%$ to $40 \%$ affect the temporal structure of the signals (ANOVA on ranks: $\mathrm{H}_{\text {pulse }}=68.5 ; \mathrm{H}_{\text {pause }}=64.8$; $\mathrm{H}_{\text {pulse sequence }}=15.2 ; \mathrm{H}_{\text {duty cycle }}=101.4$; Dunn's comparison). Again, only the decrease from $40 \%$ to $20 \%$ sugar water resulted in a significant change of the signals: the median pulse duration decreased from $0.473 \mathrm{~s}$ to $0.226 \mathrm{~s}$, while the median pause duration increased from $0.021 \mathrm{~s}$ to $0.122 \mathrm{~s}$ (Figs. 4, 6). Accordingly, the duty cycle was lowest after the change to $20 \%$ sugar water. The pulse sequence did not significantly decrease under these conditions, but the values for the $20 \%$ sugar water concentration were significantly lower than those for the $60 \%$ concentration.

The main frequency component of the vibrations (Fig. 4e) remained on a constant level 

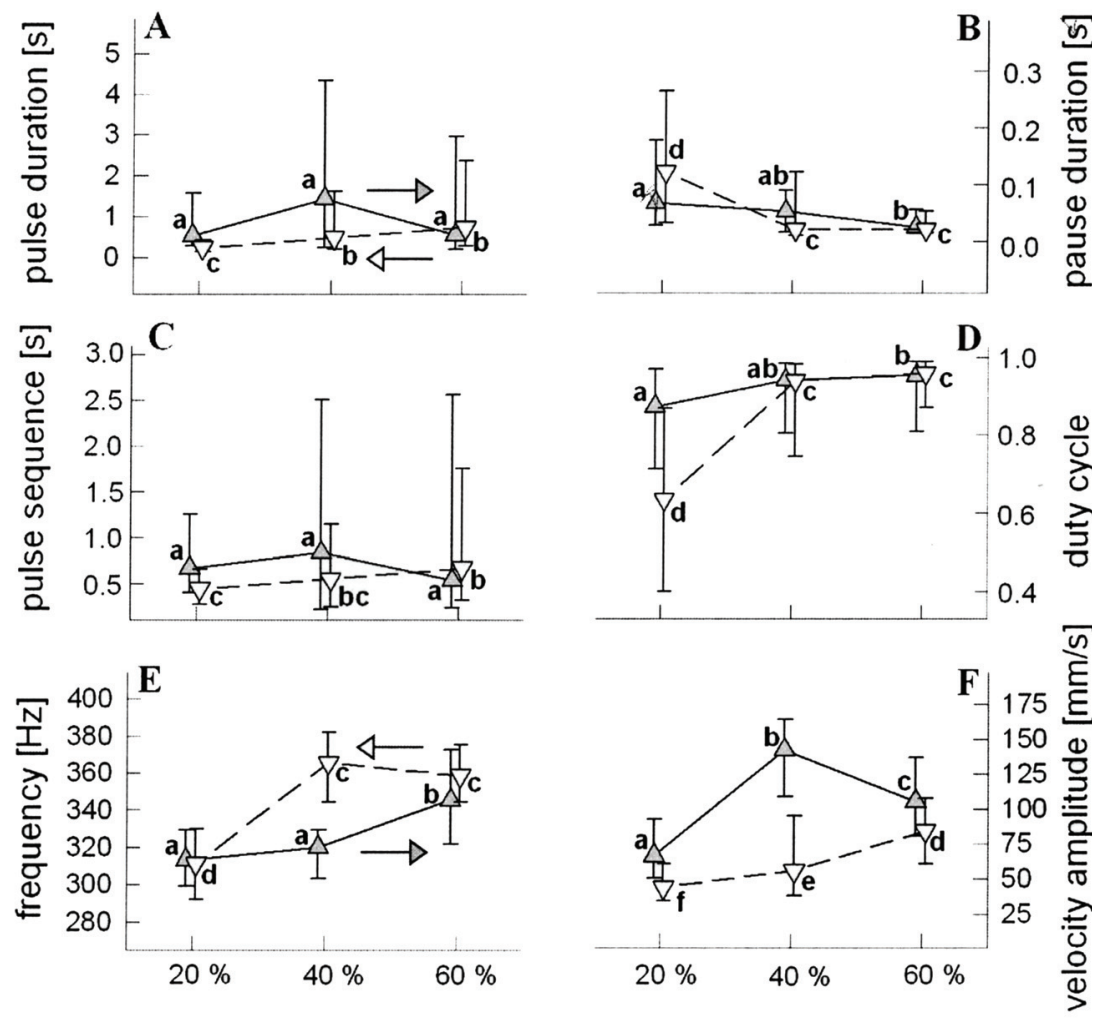

\section{sugar water concentration $[\mathrm{w} / \mathrm{w}]$}

Fig. 4. Vibrational signals of $S$. aff. depilis. When increasing $(\triangle)$ the sugar water concentration neither pulse duration (A), pause duration (B), pulse sequence (= pulse duration + successive pause) (C), nor duty cycle (= pulse/pulse sequence) $(\mathbf{D})$ changed significantly. Only the decreasing $(\nabla)$ change from the $40 \%$ to the $20 \%$ sugar water concentration elicited significantly shortest pulses (A), longest pauses (B), and lowest duty cycles (D) of the signals. (E) During the series of increasing concentrations the main frequency contained in the pulses was highest when $60 \%$ sugar water was offered and during the series of decreasing concentrations it was lowest when $20 \%$ was offered. (F) The velocity amplitude of the pulses (mm/s) was highest at $40 \%$ during the series of increasing concentrations. The amplitudes significantly decreased with each reduction of the sugar concentration.

during the first two hours of both test series. It did not differ significantly when increasing the sugar concentration from $20 \%$ (median of $313.4 \mathrm{~Hz}$ ) to $40 \%$ sugar water (median of $319.9 \mathrm{~Hz}$ ) (ANOVA on ranks: $\mathrm{H}=123.8$; Dunn's comparison). A significant increase (median of $345.3 \mathrm{~Hz}$ ) occurred after the change to the $60 \%$ concentration (Dunn's comparison). However, when the $60 \%$ sugar water was offered first and the $40 \%$ sugar water second in a series of decreasing concentrations the frequencies of the vibrations were not different from each other (median at $60 \%=358.4 \mathrm{~Hz}$, at
$40 \%=365.5 \mathrm{~Hz}$ ) (ANOVA on ranks: $\mathrm{H}=$ 237.1; Dunn's comparison). Only after changing from $40 \%$ to $20 \%$ sugar water the main frequency component dropped significantly to a median of $311 \mathrm{~Hz}$ (Dunn's comparison).

The velocity amplitude (Fig. 4f) significantly increased from $66.6 \mathrm{~mm} / \mathrm{s}$ (median) at $20 \%$ to $142.1 \mathrm{~mm} / \mathrm{s}$ (median) at $40 \%$ when sugar water was offered in a series of increasing concentrations but it decreased again after the change from $40 \%$ to $60 \%$ sugar water $(105.1 \mathrm{~mm} / \mathrm{s})($ ANOVA on ranks: $\mathrm{H}=147.2$; Dunn's comparison). This pattern does not 

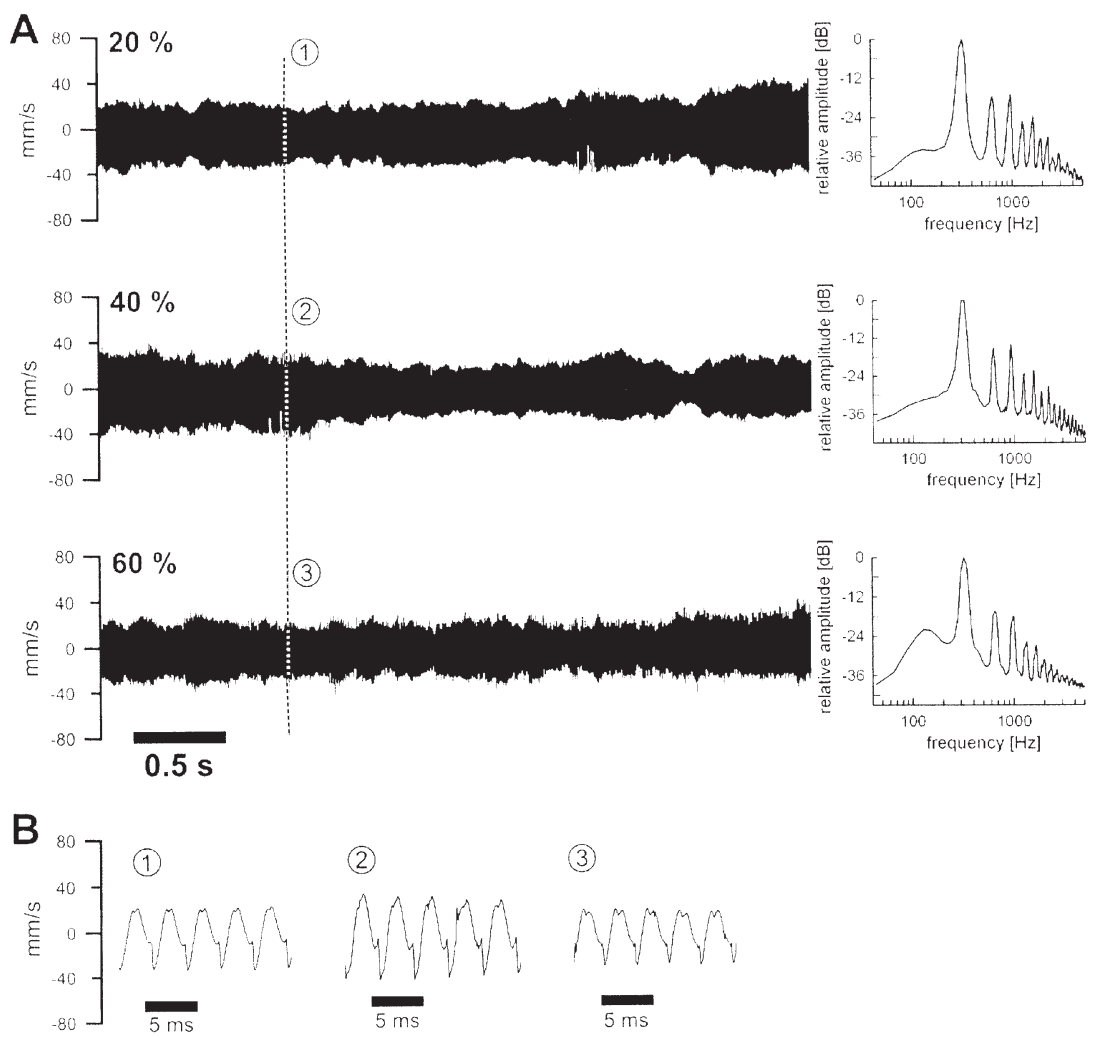

Fig. 5. (A) Left: characteristic vibrational signals produced by the same forager when $20 \%, 40 \%$, and $60 \%$ w/w sugar water was offered in an increasing order within three hours. Right: the signals' frequency power spectra (FFT, 1024 pts) with main frequency $(0 \mathrm{~dB})$ and its harmonics. (B) Expanded sections of the thorax vibrations when (1) $20 \%$, (2) $40 \%$, and (3) $60 \%$ w/w sugar water was offered, respectively.

resemble any of the corresponding changes of the energy gain at the food source (Fig. 1). By contrast, during the series of decreasing concentrations the median amplitudes of the signals decreased significantly from $84.4 \mathrm{~mm} / \mathrm{s}$ at $60 \%$ to $56.3 \mathrm{~mm} / \mathrm{s}$ at $40 \%$ and to $44.2 \mathrm{~mm} / \mathrm{s}$ at $20 \%$, which does parallel the decreases of the energy intake (ANOVA on ranks: $\mathrm{H}=135.5$; Dunn's comparison).

\section{DISCUSSION}

Our findings imply that the recruitment intensity of Scaptotrigona aff. depilis does not directly reflect the food's actual sugar concentration or energy gain but instead depends on the history of its changes. Neither were increasingly richer food sources exploited more inten- sively than food sources with constant food profitability nor did the recruiters increase their activity inside the nest. However, the number of recruits significantly decreased after each reduction of the sugar water concentration and the intranidal activity significantly decreased when the concentration was reduced from $40 \%$ to $20 \% \mathrm{w} / \mathrm{w}$.

\subsection{Sugar concentration of the food source affects energy gain}

When Scaptotrigona aff. depilis was offered three different sugar water concentrations taken from the biologically relevant range (Roubik et al., 1995), energy intake at the food source changed significantly. The profitability of nectar sources is determined by both sugar concentration and sugar flow rate (Núñez, 

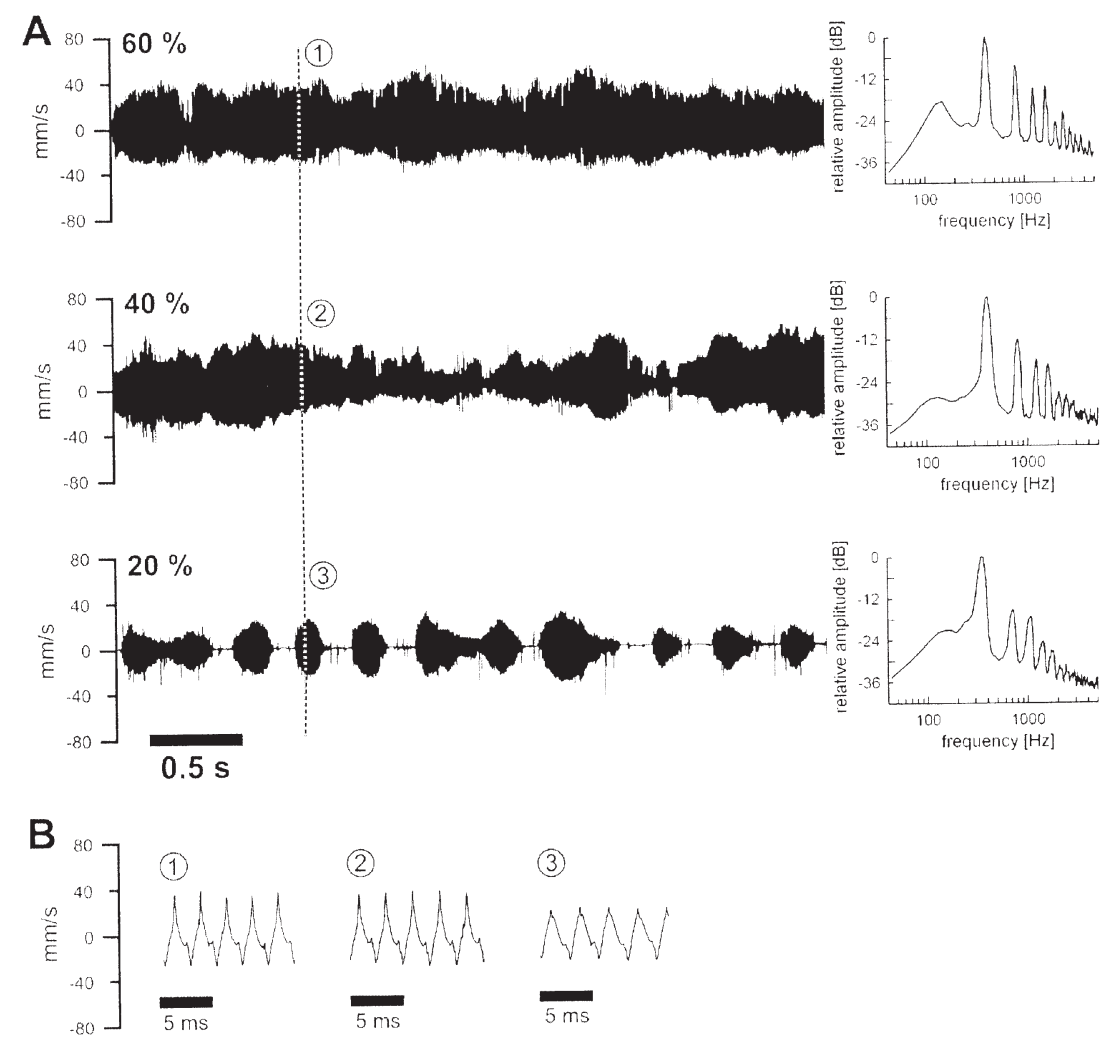

Fig. 6. (A) Left: vibrational signals of the same forager when $60 \%, 40 \%$, and $20 \%$ w/w sugar water was offered in a decreasing order within three hours. Right: the signals' frequency power spectra (FFT, 1024 pts) with main frequency $(0 \mathrm{~dB})$ and its harmonics. (B) Expanded sections of the vibrations when (1) $60 \%$, (2) $40 \%$, and (3) $20 \%$ w/w sugar water was offered.

1966). Honeybees may use the sugar uptake rate $(\mathrm{mg} / \mathrm{s})$ or the amount of sugar carried by the forager $(\mathrm{mg})$ as indicators of energy gain (Farina and Núñez, 1991). In the present study with Scaptotrigona aff. depilis both parameters and therefore profitability significantly increased with sugar water concentration $(20 \%, 40 \%$, $60 \%$ w/w). Similarly, Roubik et al. (1995) found that energy gains of foraging Scaptotrigona barrocoloradensis, $S$. pectoralis, and $S$. luteipennis increased with sugar concentration of the food source.

\subsection{Number of recruits at the food source does not simply correlate with sugar concentration}

The number of recruited nestmates did not simply correlate with the actual sucrose con- centration of the food source in Scaptotrigona aff. depilis. It did not change with increasing concentrations whereas it significantly decreased when the sucrose concentration decreased. Obviously the bees gave more weight to a decrease of the food profitability than to its increase. The decreasing number of recruited nestmates can not be ascribed to a depletion of available recruits in the colony. We measured the flight activity by counting the number of bees leaving the nest per minute. $50 \pm 14$ bees/ min left the colony on days of an experiment which indicates a number of foragers substantially larger than the number of recruits considered in our study. We therefore exclude the possibility of a depletion of available recruits after a mean of 38 bees had arrived at the feeding site during the periods with $60 \%$ sugar water. 
Both the recruiter and the nestmates save time and energy by stopping the recruitment to food sources of decreasing profitability. Thereby the re-allocation of the colony's foraging force to more valuable food sources may be facilitated as well (Biesmeijer and Ermers, 1999).

\subsection{Intranidal recruitment behavior does not intensify with increasing sugar concentration}

The intensity of intranidal recruitment behavior of Scaptotrigona aff. depilis did not reflect the actual profitability of the food source and foragers did not react to increases of sugar water concentration. The only change found was a reduction of their activity with the reduction of the sugar concentration from $40 \%$ to $20 \%$ w/w. Similarly, in some cases honeybees reacted stronger to decreases than to increases of food profitability (Raveret-Richter and Waddington, 1993; Wainselboim et al., 2002; Wainselboim and Farina, 2003) and even stopped dancing when the sugar concentration was reduced from $1.8 \mathrm{M}$ to $0.6 \mathrm{M}(\sim 50 \%$ to $20 \%$ w/w) (de Marco and Farina, 2001).

The vast majority of the studies available, however, emphasizes the capability of honeybees to adjust their recruitment activity to both increasing and decreasing food profitability. Their waggle dances, round dances, and sound production inside the nest intensify when they feed on highly profitable nectar sources and decrease with a reduction of food profitability (von Frisch, 1965; Waddington, 1982; Seeley and Towne, 1992; Waddington and Kirchner, 1992; Seeley 1994, 1995; Seeley et al., 2000; de Marco and Farina, 2001). As a consequence, the recruitment of new foragers to highly valuable food sources always exceeds that to low quality food sources (Boch, 1956; von Frisch, 1965; Seeley, 1986, 1995; Seeley et al., 1991; Seeley and Towne, 1992; Fernández and Farina, 2002). Thus, the adjustment of recruitment intensity of individual honeybee foragers results in a cascade of positive feedback on the level of the entire colony.

According to the present study there is no such positive feedback in Scaptotrigona aff. depilis. Our data rather suggest that as long as the exploitation of the food source seems worthwhile the intranidal recruitment activity remains the same. It obviously needed a rigorous decrease of the food profitability to a very low value $(20 \% \mathrm{w} / \mathrm{w})$ to change the behavior of the recruiters in such a way, that nearly no new nestmates were recruited anymore. It remains unexplained why the number of recruits decreased after changing the sugar water concentration from $60 \%$ to $40 \%$ while at the same time the intranidal behavior of the foragers did not change (Fig. 2). The reason may be a reduction in extranidal communication (scent trail laying, marking the feeding site). Further experiments will have to clarify this.

For an explanation of the recruitment pattern found in the present study the scent trail is likely to be important. The laying of a scent trail is typical for the genus Scaptotrigona (Lindauer and Kerr, 1958; Kerr et al., 1963; Schmidt et al., 2003; Sánchez et al., 2004) and sometimes referred to as indirect recruitment behavior (Sumpter and Pratt, 2003). By comparison, in scent trail laying ants an increasing number of foragers increasingly reinforces the scent trail between the nest and the food source. The resulting positive feedback on the number of foragers has its main cause outside the nest: The stronger the scent trail the faster the buildup of the foraging force (Breed et al., 1987; Pasteels et al., 1987; Beckers et al., 1990; Mercier and Lenoir, 1999; Sumpter and Beekman, 2003).

It has been demonstrated both for a scent trail laying stingless bee, Trigona recursa (Schmidt et al., 2006), and for scent trail laying ants (Beckers et al., 1990, 1993; Sumpter and Beekman, 2003) that the more profitable food source was exploited by more nestmates than the less profitable one whenever they were discovered simultaneously and experimental interference with the recruitment process was avoided. In our experiments with Scaptotrigona aff. depilis an accumulation of foragers at the food source was prevented by removing all newcomers. Scaptotrigona depilis, the species most closely related to the one used by us, brought more than one thousand individuals to an artificial food source of constant quality when interference with the recruitment process was avoided (Jarau et al., 2003). We assume that a faster build-up of the foraging force of $S$. aff. depilis at richer food sources under unrestrained conditions would indeed entail their more intensive exploitation. 


\subsection{Vibrational signals are less vigorous after reducing the sugar concentration to $20 \%$}

Significant changes of the vibrational signals of Scaptotrigona mainly occurred after the reduction of the sugar water concentration from $40 \%$ to $20 \%$ (shortest pulse duration, longest pause duration, lowest duty cycle, lowest main frequency, lowest velocity amplitude). So far, sounds and vibrational signals have only been recorded in the non-scent trail laying genus Melipona and only recent investigations focused on the correlation between sugar water concentration and vibrational and airborne sound signals, respectively (Melipona costaricensis: Aguilar and Briceño, 2002; M. seminigra: Hrncir et al., 2002, 2004b; M. mandacaia and M. bicolor: Nieh et al., 2003). Although the experimental designs of these studies differed, pulse duration was found to be significantly shorter and pause duration significantly longer when the bees fed on sugar water of low instead of high sugar concentrations (Aguilar and Briceño, 2002; Nieh et al., 2003) or energy gains (Hrncir et al., 2002, 2004b). Similarly, in Scaptotrigona aff. depilis the vibrational signals were less vigorous (shorter pulses, longer pauses) after the decrease of the sugar concentration to $20 \%$ than when the bees were feeding on higher concentrations.

In Scaptotrigona aff. depilis the pulse duration varies enormously (coefficient of variation between $122 \%$ and $189 \%$; CV $=1 \mathrm{SD} \times 100$ / mean, Sokal and Rohlf, 1995). The same is known of Melipona (see Hrncir et al., 2004b, Tab. I). Thus, changes of the vibratory signals might not be "understood" by the nestmates. The recruiters' behavior varied less in regard to running speed $(\mathrm{CV}=20-29 \%)$ and jostling contacts $(\mathrm{CV}=37-57 \%)$ than in regard to the vibrational signals. We conclude that the agitated run of a recruiter inside the nest with its jostling contacts is responsible for the general stimulation of nestmates, as are the vibrational signals. Detailed information on the food profitability does not seem to be transmitted by the intranidal behavior. Only after the reduction from $40 \%$ to $20 \%$ sugar concentration the foragers' intranidal recruitment communication changed in such a way that the recruitment of newcomers ceased.
We also assume, that the vibratory signals do not inform on the location of the food source. In our experiments we never changed the distance between the nest and the food source as it was previously done with various species of Melipona (Esch, 1967; Nieh and Roubik, 1998; Hrncir et al., 2000; Aguilar and Briceño, 2002; Nieh et al., 2003). However, variability is similarly high in both cases. In case of Scaptotrigona a scent trail leads the recruits to the food source. Thus receiving information on the distance to the food source inside the nest does not seem necessary.

The present work focused on the individual forager, i.e. the sender of the recruitment message. Future studies will concentrate on the receivers of the message, i.e. the nestmates. It is them who need to understand the meaning of a message before they leave the nest in search for the indicated food source.

\section{ACKNOWLEDGEMENTS}

We are indebted to Sidnei Mateus for helping us and the bees whenever he could. Our sincere thanks go to Stefan Jarau and Michael Hrncir for their help and fruitful discussions. This work was supported by grants $\mathrm{P} 14328$ and $\mathrm{P} 17530$ of the Austrian Science Fund (FWF) to FGB, the Karl von Frisch prize of the German Zoological Society awarded to FGB, and a grant of the BMBWK of Austria to VMS.

Résumé - Recrutement chez une abeille sans aiguillon déposant une trace odorante (Scaptotrigona aff. depilis) : modification avec la baisse mais non avec la hausse du gain d'énergie. Chez les abeilles sans aiguillon (Apidae, Meliponini), comme chez d'autres insectes sociaux, la profitabilité de la source de nourriture influence le recrutement. Il avait été montré jusqu'à présent chez des espèces ne laissant pas de trace odorante que les abeilles étaient recrutées en nombre d'autant plus grand que la source de nourriture était avantageuse (Biesmeijer et Ermers, 1999). Ce travail étudie pour la première fois comment la concentration en sucre de la nourriture influence le recrutement d'une abeille sans aiguillon, qui conduit les recrues à la source de nourriture le long d'un chemin olfactif. On a fait butiner trois abeilles à une source de nourriture durant $3 \mathrm{~h}$ et le nombre de recrues par $\mathrm{h}$ a été compté. En outre le comportement de Scaptotrigona aff. depilis à l'entrée de la colonie a été filmé et les vibrations du thorax enregistrées avec un vibromètre laser. Les concentrations en sucre utilisées $(20 \%$, $40 \%, 60 \%$ en poids) étaient dans le domaine des 
valeurs biologiques. Le sirop a été consommé en plus grande quantité $(\mu \mathrm{L})$ quand sa concentration était de $20 \%$ et la prise de nourriture a été la plus longue avec la concentration de $60 \%$ (Fig. 1). Quand on a offert une concentration en sucre constante, le nombre de recrues à la source de nourriture est resté lui aussi constant (Fig. 2). Ce fut aussi le cas lorsqu'on a offert une source de nourriture avec une profitabilité augmentant d'heure en heure. Ce n'est qu'en diminuant la profitabilité que le recrutement horaire a chuté (Fig. 2). L'analyse du comportement de recrutement à l'intérieur du nid a montré que ni leur activité de bousculade ni leur vitesse de déplacement dans le nid n'augmentaient lorsqu'on leur offrait une profitabilité croissante (Fig. 3). Quand la profitabilité a diminué les butineuses n'ont réduit leur activité qu'à partir de la concentration de $20 \%$ (Fig. 3). La structure dans le temps des vibrations du thorax ne s'est pas modifiée quand la profitabilité a augmenté (Figs. 4, 5). Ce n'est que lorsque la concentration est tombée à $20 \%$ que les impulsions sont devenues significativement plus courtes et les pauses significativement plus longues (Figs. 4, 6).

De ces résultats on conclut que le recrutement de Scaptotrigona aff. depilis ne dépend pas directement de la concentration en sucre de la nourriture, mais des changements de la profitabilité. Les abeilles ne modifient leur activité que lorsque la concentration tombe à $20 \%$ et le recrutement de membres de la colonie est arrêté. Nous supposons qu'il s'agit d'un mécanisme qui conduit la colonie à cesser le recrutement pour des sources qui se déprécient afin de laisser les butineuses se tourner vers des sources meilleures.

abeille sans aiguillon / recrutement / butinage / profitabilité de la nourriture / communication / Apidae / Meliponini

\footnotetext{
Zusammenfassung - Rekrutierung bei einer Duftpfad legenden stachellosen Biene (Scaptotrigona aff. depilis): Änderungen bei Abnahme, aber nicht bei Zunahme des Energiegewinns. Bei stachellosen Bienen, wie bei anderen sozialen Insekten, beeinflusst die Profitabilität der Futterquelle die Rekrutierung. Bisher wurde an nicht Duftpfad legenden Arten gezeigt, dass mehr Bienen zu ertragreicheren Futterquellen rekrutiert werden als zu weniger ertragreichen (Biesmeijer und Ermers, 1999). In der vorliegenden Arbeit wurde erstmals untersucht, wie die Zuckerkonzentration des Futters die Rekrutierung einer stachellosen Biene beeinflusst, welche Rekruten entlang eines Duftpfades zur Futterquelle führt. In den Experimenten sammelten drei Bienen drei Stunden lang an einer Futterquelle und die Anzahl der pro Stunde rekrutierten Bienen wurde gemessen. Dazu wurde das Verhalten von Scaptotrigona aff. depilis im Eingangsbereich der Kolonie gefilmt und die Thoraxvibrationen mit einem Laservibrometer registriert. Die verwendeten Zuckerkonzentrationen $(20 \%, 40 \%, 60 \% \mathrm{w} / \mathrm{w})$
}

lagen im biologisch relevanten Bereich. Die Bienen nahmen am meisten Zuckerwasser $(\mu \mathrm{L})$ auf, wenn dessen Konzentration nur $20 \%$ betrug und ihre Trinkdauer war am längsten, wenn sie $60 \%$ Zuckerwasser aufnahmen (Abb. 1). Die Profitabilität der Futterquelle (mg Zucker pro Honigmagenfüllung bzw. mg Zuckeraufnahme pro Sekunde) nahm mit der Konzentration signifikant zu (Abb. 1). Wenn eine konstante Zuckerkonzentration geboten wurde, blieb auch die Anzahl der Rekruten an der Futterquelle konstant (Abb. 2). Dies war ebenso der Fall, wenn den Sammelbienen eine Futterquelle mit stündlich ansteigender Profitabilität geboten wurde. Nur nach einer Abnahme der Profitabilität sank der stündliche Rekrutierungserfolg signifikant (Abb. 2). Die Analyse des intranidalen Rekrutierungsverhaltens zeigte, dass die Bienen weder ihre Rempelaktivität noch ihre Laufgeschwindigkeit im Nest erhöhten, wenn ihnen Futter mit ansteigender Profitabilität angeboten wurde (Abb. 3). Bei abnehmender Profitabilität reduzierten die Sammelbienen ihre Aktivität nur, nachdem auf die $20 \%$ Konzentration gewechselt worden war (Abb. 3). Auch die zeitliche Struktur der Thoraxvibrationen veränderte sich nicht, wenn die Profitabilität anstieg (Abb. 4, 5). Nur wenn die Zuckerkonzentration auf $20 \%$ sank, waren die Pulse signifikant kürzer und die Pausen signifikant länger als bei den höheren Konzentrationen (Abb. 4, 6).

Die Ergebnisse lassen den Schluss zu, dass die Rekrutierung von $S$. aff. depilis nicht direkt von der Zuckerkonzentration des Futters abhängt, sondern von den Veränderungen der Profitabilität. Die Bienen änderten ihre Aktivität nur, wenn die Konzentration auf $20 \%$ sank. Zur selben Zeit wurde die Rekrutierung von Nestgenossinnen eingestellt. Wir nehmen an, dass es sich hier um einen Mechanismus handelt, der dazu führt, dass die Kolonie ihre Rekrutierung zu schlechter werdenden Futterquellen einstellt, damit die Sammlerinnen sich besseren Futterquellen zuwenden können.

Stachellosen Biene / Rekrutierung / Sammelverhalten / Ertragswert der Nahrung / Kommunikation

\section{REFERENCES}

Aguilar I., Briceño D. (2002) Sounds in Melipona costaricensis (Apidae: Meliponini): effect of the sugar concentration and nectar source distance, Apidologie 33, 375-388.

Bartareau T. (1996) Foraging behaviour of Trigona carbonaria (Hymenoptera: Apidae) at multiplechoice feeding stations, Austr. J. Zool. 44, 143153.

Beckers R., Deneubourg J.L., Goss S., Pasteels J.M. (1990) Collective decision making through food recruitment, Insectes Soc. 37, 258-267.

Beckers R., Deneubourg J.L., Goss S. (1993) Modulation of trail laying in the ant Lasius niger 
(Hymenoptera, Formicidae) and its role in the collective selection of a food source, J. Insect Behav. 6, 751-759.

Biesmeijer J.C., Ermers C.W. (1999) Social foraging in stingless bees: how colonies of Melipona fasciata choose among nectar sources, Behav. Ecol. Sociobiol. 46, 129-140.

Biesmeijer J.C., de Vries H. (2001) Exploration and exploitation of food sources by social insect colonies: a revision of the scout-recruit concept, Behav. Ecol. Sociobiol. 49, 89-99.

Boch R. (1956) Die Tänze der Bienen bei nahen und fernen Trachtquellen, Z. Vgl. Physiol. 38, 136167.

Breed M.D., Fewell J.H., Moore A.J., Williams K.R. (1987) Graded recruitment in a ponerine ant, Behav. Ecol. Sociobiol. 2, 407-411.

Cassill D. (2003) Rules of supply and demand regulate recruitment to food in an ant society, Behav. Ecol. Sociobiol. 54, 441-450.

Chenlo F., Moreira R., Pereira G. (2002) Osmotic dehydration: viscosity of solutions of sucrose and sodium chloride, Actas del $2^{\circ}$ congreso español de ingeniería de alimentos, University of Lleida, Spain.

Esch H. (1967) Die Bedeutung der Lauterzeugung für die Verständigung der stachellosen Bienen, Z. Vgl. Physiol. 56, 199-220.

Farina W.M., Núñez J.A. (1991) Trophallaxis in the honey bee, Apis mellifera (L.) as related to the profitability of food sources, Anim. Behav. 42, 389-394.

Fernández P.C., Farina W.M. (2002) Individual recruitment in honeybees, Apis mellifera L., The effect of food source profitability on the rate of bees arriving at the feeding place, Acta Ethol. 4, 103-108.

Fewell J.H., Harrison J.H., Stiller T.M., Breed M.D. (1992) Distance effects on the resource profitability and recruitment in the giant tropical ant, Paraponera clavata, Oecologia 92, 542-547.

von Frisch K. (1965) Tanzsprache und Orientierung der Bienen, Springer Verlag, Berlin, Heidelberg, New York.

Hrncir M., Jarau S., Zucchi R., Barth F.G. (2000) Recruitment behavior in stingless bees, Melipona scutellaris and M. quadrifasciata. II. Possible mechanisms of communication, Apidologie 31, 93-113.

Hrncir M., Zucchi R., Barth F.G. (2002) Mechanical recruitment signals in Melipona vary with gains and costs at the food source, Anais do encontro sobre abelhas 5, 172-175.

Hrncir M., Jarau S., Zucchi R., Barth F.G. (2004a) Thorax vibrations of a stingless bee (Melipona seminigra): I. No influence of visual flow, J. Comp. Physiol. A 190, 539-548.

Hrncir M., Jarau S., Zucchi R., Barth F.G. (2004b) Thorax vibrations of a stingless bee (Melipona seminigra): II. Dependence on sugar concentration, J. Comp. Physiol. A 190, 549-560.
Jarau S., Hrncir M., Zucchi R., Barth F.G. (2000) Recruitment behavior in stingless bees, Melipona scutellaris and M. quadrifasciata. I. Foraging at food sources differing in direction and distance, Apidologie 31, 81-91.

Jarau S., Hrncir M., Schmidt V.M., Zucchi R., Barth F.G. (2003) Effectiveness of recruitment behavior in stingless bees (Apidae, Meliponini), Insectes Soc. 50, 365-374.

Johnson L.K. (1987) Communication of food source location by the stingless bee Trigona fulviventris, in: Eder J., Rembold H. (Eds.), Chemistry and biology of social insects, Verlag J. Peperny, München, pp. 698-699.

Kerr W.E., Ferreira A., de Mattos N.S. (1963) Communication among stingless bees - additional data (Hymenoptera: Apidae), J. N.Y. Entomol. Soc. 71, 80-90.

Lindauer M. (1948) Über die Einwirkung von Duftund Geschmackstoffen sowie anderer Faktoren auf die Tänze der Bienen, Z. Vgl. Physiol. 31, 348-412.

Lindauer M., Kerr W.E. (1958) Die gegenseitige Verständigung bei den stachellosen Bienen, Z. Vgl. Physiol. 41, 405-434.

de Marco R.J., Farina W.M. (2001) Changes in food source profitability affect the trophallactic and dance behavior of forager honeybees (Apis mellifera L.), Behav. Ecol. Sociobiol. 50, 441449.

Mercier J.L., Lenoir A. (1999) Individual flexibility and choice of foraging strategy in Polyrhachis laboriosa F. Smith (Hymenoptera, Formicidae), Insectes Soc. 46, 267-272.

Nicolis S.C., Deneubourg J.L. (1999) Emerging patterns and food recruitment in ants: an analytical study, J. Theor. Biol. 198, 575-592.

Nieh J.C., Roubik D.W. (1998) Potential mechanisms for the communication of height and distance by a stingless bee, Melipona panamica, Behav. Ecol. Sociobiol. 43, 387-399.

Nieh J.C., Contrera F.A.L., Rangel J., ImperatrizFonseca V.L. (2003) Effect of food location and quality on recruitment sounds and success in two stingless bees, Melipona mandacaia and Melipona bicolor, Behav. Ecol. Sociobiol. 55, 87-94.

Núñez J.A. (1966) Quantitative Beziehungen zwischen den Eigenschaften von Futterquellen und dem Verhalten von Sammelbienen, Z. Vgl. Physiol. 31, 348-412.

Pasteels J.M., Deneubourg J.L., Goss S. (1987) Selforganization mechanisms in ant societies (I): trail recruitment to newly discovered food sources, Experientia Suppl. 54, 155-175.

Raveret-Richter M., Waddington K.D. (1993) Past foraging experience influences honey bee dance behavior, Anim. Behav. 46, 123-128.

Roubik D.W. (1989) Ecology and natural history of tropical bees, Cambridge University Press, New York. 
Roubik D.W., Yanega D., Aluja M., Buchmann S.L., Inouye D.W. (1995) On optimal nectar foraging by some tropical bees (Hymenoptera: Apidae), Apidologie 26, 197-211.

Sánchez D., Nieh J.C., Hénaut Y., Cruz L., Vandame R. (2004) High precision during food recruitment of experienced (reactivated) foragers in the stingless bee Scaptotrigona mexicana (Apidae, Meliponini), Naturwissenschaften 91, 346-349.

Schmidt V.M., Zucchi R., Barth F.G. (2003) A stingless bee marks the feeding site in addition to the scent path (Scaptotrigona aff. depilis Moure 1942), Apidologie 34, 237-248.

Schmidt V.M., Schorkopf D.L.P., Hrncir M., Zucchi R., Barth F.G. (2006) Collective foraging in a scent path laying stingless bee (Trigona recursa): Dependence on food profitability and sequence of discovery, Anim. Behav. (in press).

Seeley T.D. (1986) Social foraging in honey bees: how colonies allocate foragers among patches of flowers, Behav. Ecol. Sociobiol. 19, 343-354.

Seeley T.D. (1994) Honey bee foragers as sensory units of their colonies, Behav. Ecol. Sociobiol. 34, 51-62.

Seeley T.D. (1995) The wisdom of the hive, Harvard University Press, Cambridge, Mass.

Seeley T.D., Towne W.F. (1992) Tactics of dance choice in honey bees: do foragers compare dances? Behav. Ecol. Sociobiol. 30, 59-69.

Seeley T.D., Camazine S., Sneyd J. (1991) Collective decision-making in honey bees: how colonies choose among nectar sources, Behav. Ecol. Sociobiol. 28, 277-290.
Seeley T.D., Mikheyev A.S., Pagano G.P. (2000) Dancing bee tunes both duration and rate of waggle-run production in relation to nectarsource profitability, J. Comp. Physiol. A 186, 813-819.

Sokal R.R., Rohlf F.J. (1995) Biometry, 3rd ed., Freeman, New York.

Sumpter D.J.T., Beekman M. (2003) From nonlinearity to optimality: pheromone trail foraging by ants, Anim. Behav. 66, 273-280.

Sumpter D.J.T., Pratt S.C. (2003) A modelling framework for understanding social insect foraging, Behav. Ecol. Sociobiol. 53, 131-144.

Waddington K.D. (1982) Honey bee foraging profitability and round dance correlates, J. Comp. Physiol. A 148, 297-301.

Waddington K.D., Kirchner W.H. (1992) Acoustical and behavioral correlates of profitability of food sources of honey bee round dances, Ethology 92, $1-6$.

Wainselboim A.J., Farina W.M. (2003) Trophallaxis in honeybees, Apis mellifera (L.), as related to their past experience at the food source, Anim. Behav. 66, 791-795.

Wainselboim A.J., Roces F., Farina W.M. (2002) Honeybees assess changes in nectar flow within a single foraging bout, Anim. Behav. 63, 1-6.

Weast R.C., Lide D.R., Astle M.J., Beyer W.H. (Eds.) (1989) CRC Handbook of chemistry and physics, 70th ed., CRC Press, Boca Raton Florida. 